folk/ed. $2021 ; 27(2):$ 597-608

DOI: $10.22559 /$ folklor.1633

\title{
Values Folklore in West Lampung Indonesia
}

\author{
Endonezya- Batı Lampung'daki Değerler Folkloru
}

\author{
Sudjarwo* \\ Albet Maydiantoro** \\ Listumbinang Halengkara**
}

\begin{abstract}
This study aimed at making inventory and mapping the folklore in West Lampung of Lampung Province and finding out the cultural values contained in folklore. This type of research was qualitative descriptive where the population in this study was the people who live in West Lampung. The samples respondents were selected through purposive sampling with snawball method. The key informant who acted as the respondents were determined by specific criteria; such as community leaders, traditional leaders, people who know directly or indirectly on folklore, or a formal government leaders. There were two types of data used in this
\end{abstract}

Geliş tarihi (Received): 24.10.2020 - Kabul tarihi (Accepted): 23.02.2021

* Prof. Dr., M.S. Indonesia University of Lampung. sudjarwo@gmail.com. ORCID. 0000-0002-8134-7238

**(corresponding author) S.Pd., M.Pd. University of Lampung. albet.maydiantoro@fkip.unila.ac.id. ORCID.00000003-4017-8324

*** S.Si., M.Sc. Indonesia University of Lampung. halengkara@gmail.com. ORCID 0000-0002-0165-9611 
study, namely primary and secondary data. Primary data were obtained directly from interviews to the respondents while secondary data were obtained indirectly through books and historical records related to the research theme. Data analysis was conducted to determine the cultural values contained in folklore. The results showed that there were seven folklores in West Lampung, namely: 1) Si Pahit Lidah and Si Mata Empat (The Story of the Bitter Tongue and the Four Eyes), 2) Naga Danau Ranau (The Dragon of Ranau Lake), 3) Asal Mula Nama Desa Sri Menanti (The origin of Sri Menant Village), 4) Kisah Batu Katai dan Larangan Menikah Antara Warga Desa Gandasuli dan Desa Kunyanyan (Story of the Katai Stone and Prohibition Marriage between Residents of Gandasuli and Kunyanyan Village), 5) Batu Kepampang (Kepampang Stone), 6) Kisah Si Beguk Sakti (The Story of the Magic Mumps), and 7) Asal-usul Nama Way Mengaku (The Origins of Way Mengaku). The values contained in the folklore were social values, religious values, customs,vanity, greed, faithfulness, and the envy.

Keywords: folklore, values, cultural, West Lampung, Indonesia

\section{Öz}

$\mathrm{Bu}$ çalışma, Lampung Eyaleti, West Lampung'daki folklorun envanterini çıkarmayı ve haritalamayı ve folklorun içerdiği kültürel değerleri ortaya çıkarmayı amaçlamaktadır. Bu araştırma türü, West Lampung'da yaşayan insanların hedef kitle olduğu ortamlarda nitel tanımlayıcıdır. Örnekler, kartopu yöntemi ile amaçlı örnekleme yoluyla seçilmiştir. Yanıtlayanlar olarak hareket eden kaynak kişiler, belirli kriterlere göre belirlendi; topluluk liderleri, geleneksel liderler, folklor hakkında doğrudan veya dolaylı olarak bilgi sahibi olan kişiler veya resmi bir hükümet liderleri gibi. Bu çalışmada kullanılan birincil ve ikincil veri olmak üzere iki tür veri vardır. Birincil veriler doğrudan katılımcılarla yapılan görüşmelerden elde edilirken, ikincil veriler dolaylı olarak araştırma temasıyla ilgili kitaplar ve tarihsel kayıtlar aracılığıyla elde edilmiş; yazılı ve sözlü kaynaklardan yararlanılmıştır. Çalışmada folklorun içerdiği kültürel değerleri belirlemek için veri analizi yapılmıştır. Sonuçlar, West Lampung'da yedi folklor ürünü ortaya konulmuştur: 1) Si Pahit Lidah ve Si Mata Empat (Acı Dilin Hikâyesi ve Dört Göz), 2) Naga Danau Ranau (Ranau Gölü Ejderhası), 3 ) Asal Mula Nama Desa Sri Menanti (Sri Menant Köyü’nün kökeni), 4) Kisah Batu Katai ve Larangan Menikah Antara Warga Desa Gandasuli dan Desa Kunyanyan (Katai Taşının Hikâyesi ve Gandasuli ve Kunyanyan Köyü Sakinleri Arasındaki Yasak Evlilik), 5 ) Batu Kepampang (Kepampang Stone), 6) Kisah Si Beguk Sakti (The Story of the Magic Mumps), ve 7) Asal-usul Nama Way Mengaku (The Origins of Way Mengaku). Bu ürünlerde saptanan folklorik değerler; sosyal, dinsel, geleneksel değerler; kibir, açgözlülük, sadakat ve kıskançlık olarak belirlenmiştir.

Anahtar sözcükler: folklor, değerler, kültürel, West Lampung, Endonezya 


\section{Introduction}

Folklore is one of the cultural wealth of Indonesia. Folklore itself can be defined as the essence of a culture that is passed down by word of mouth until now. Folklore is still regarded as a model of humanity and guidance on human actions. Folklore tends to have a pattern of stories and contains the same moral message (Bailey, 2017; Hermanto \& Sciences, 2019).

According to (Beneduce, 2016; Mabey, 2016; Zipes, Greenhill, \& Magnus-Johnston, 2015) folklore or fairy tale is the story inspired from the human imagination, delusion about their daily lives. Folklore can also be called a myth, which is not necessarily opposed to history or reality. Furthermore, (Lévi-Strauss, 2016) also interprets this myth as an expression or manifestation of the unconscious wishes of people, which is a little more inconsistent, and does not correspond to the reality in daily life.

Based on definitions above, it can be inferred that folklore is the cultural product of people who can be in the form of myths, legends or fables by word of mouth and passed down that has a good s and noble value which can be embedded in everyday life. Therefore folklore needs to be raised continously (Bronner, 2016; Deming \& Lihui, 2015).

However, in the current globalization era, where all kinds of information can be obtained quickly through television and radio as well as other IT media continues like smartphones, tablets and more various types of gadgets, most of younger generation are more familiar with the culture of other nations than they do with their own national culture. Globalization is a process in which between individuals, groups and countries interacts, relies on, relates to and affects with one another across state borders. Globalization can affect almost any aspects of the society, including the cultural aspects of a nation (Cleveland, Rojas-Méndez, Laroche, \& Papadopoulos, 2016; De Mooij, 2018; Steger, 2017).

Globalization as a symptom of the spread of values and a particular culture throughout the world (thus becoming the world's cultural or world culture). This phenomena actually has surfaced for a long time which began during the journey or expedition of Western Europe explorers to various places in the world (Unger, 2016; Wood, 2018). Even so, the development of cultural globalization begins to happen intensively in the beginning of the $20^{\text {th }}$ where technology, particularly information and communication, grows very rapidly. This causes the communication process between nations goes easier so that cultural globalization process takes place more quickly (De Mooij, 2018).

Rapid flow of information in the globalization era provides a wide range of impacts, both positive and negative impacts. One of the consequences is the spread of outside culture, especially Western culture in which their countries possesses more control an information and communication technologies compared to other countries, including Indonesia (Salehan, Kim, Lee, \& Management, 2018; Samovar, Porter, McDaniel, \& Roy, 2017; Tolkach \& Pratt, 2019).

Indonesia itself as a country that actually has a sublime culture richness tends to accept and implement the western culture on life. It is especially true in the younger generation, as literate generation with technological advances. They apply Western culture without 
selecting and filtering which multiply and are worth taking. In the end, the noble values and norms of decency, that is the identity of the Indonesian gradually, began shifting and fading, even it will be lost.

The loss of culture and identity of the Indonesian people should be avoided. Critical attitude and pro-active is needed to face this globalization era in order we can accept and we implement the good side of foreign cultures, while the bad culture and can damage the nation's culture can be avoided.

\section{Literature review}

\section{Folklore}

Folklore is a story from the past that characterizes every nation which has a diverse cultural culture including the cultural and historical wealth of each nation. folklore develops and lives in the community from generation to generation and is conveyed orally (Buchan, 2015; Nwauche, 2017). In general, folklore is anonymous or the author is unknown. types of folklore are animal stories, origin stories (legends), solace stories, humorous stories (Korom \& Lowthorp, 2020; Marsh, 2015).

The emergence of fairy tales as part of folklore, apart from serving as entertainment, is also a powerful way to pass on values and for the old society it can be seen as the only way. Because of this mission, fairy tales contain moral teachings. Folklore is a reflection of the life of the old society, whether it is in the form of fairy tales, myths, sages, or legends (Schuurmans \& Monaghan, 2015; White, 2017; Zipes et al., 2015).

Folklore or fairy tale is a story designed by a storyteller with a specific purpose. The story is made by the narrator by looking for a relationship he is telling about something that happens in nature or signs that can be seen in nature. From the story, the storyteller includes moral, religious, political, and cultural elements as well as educational elements that can be absorbed and understood by children in order to instill these values or moral elements. (Albekov, Alpysbayeva, \& Tenizbayevna, 2017; Widyahening, Wardhani, \& literature, 2016).

A fairy tale or folklore is a story about something that doesn't make sense, doesn't really happen, and is fantastical or imaginary (Grishina \& Vinokurova, 2015; Silverman, 2020; Windling, 2017) and divides into four types, namely myth, legend, fable, and sage. Myth is a story or fairy tale related to local people's beliefs about the existence of spirits, spirits, or gods. Legends are fairy tales about strange or magical natural occurrences (Mingazova, Galimullin, Galimullina, \& communication, 2016). Fables are fairy tales about animal life that are told like human life (Korhonen, 2017), and sage, which is a fairy tale about the courage of a hero in history, but the content of the story is imaginary (Mollet, 2020).

Folklore functions in addition to being a channel for maintaining and transmitting the ideas of tribes who have literature, it is also a reflection of the mind, a view of life and an expression of the sense of beauty of the people who have it (Buchan, 2015; Gates Jr, 2016). 
Folk stories or fairy tales are usually told by parents or storytellers to make children fall asleep which are told when the child is about to sleep (Grimm \& Grimm, 2016; Tatar, 2017).

As explained previously that one of the cultural wealth of Indonesia is folklore. Some Indonesian folklores are quite popular like Sangkuriang, Malin Kundang, Timun Mas (The Gold Cucumber), Bawang Merah dan Bawang Putih (The Onion and The Garlic), Cindelaras, Roro Jongrang, Keong Mas (The Golden Snail), Kasarung, Jaka Tarub, Legenda Danau Toba (The Legend of Lake Toba), and Legenda Batu Menangis (Legend of the Crying Stone). Apart from folklores above, there are several folklores which came from all regions in Indonesia which are also interesting and they contain cultural values that need to be preserved. Several of which have not been well documented and they have not been widely publicized.

\section{West Lampung Indonesia}

One of the areas in Indonesia which has a condensed cultural elements and possessing wide varieties of folklore is West Lampung, which is located in Lampung province of Sumatra Island (Figure 1).

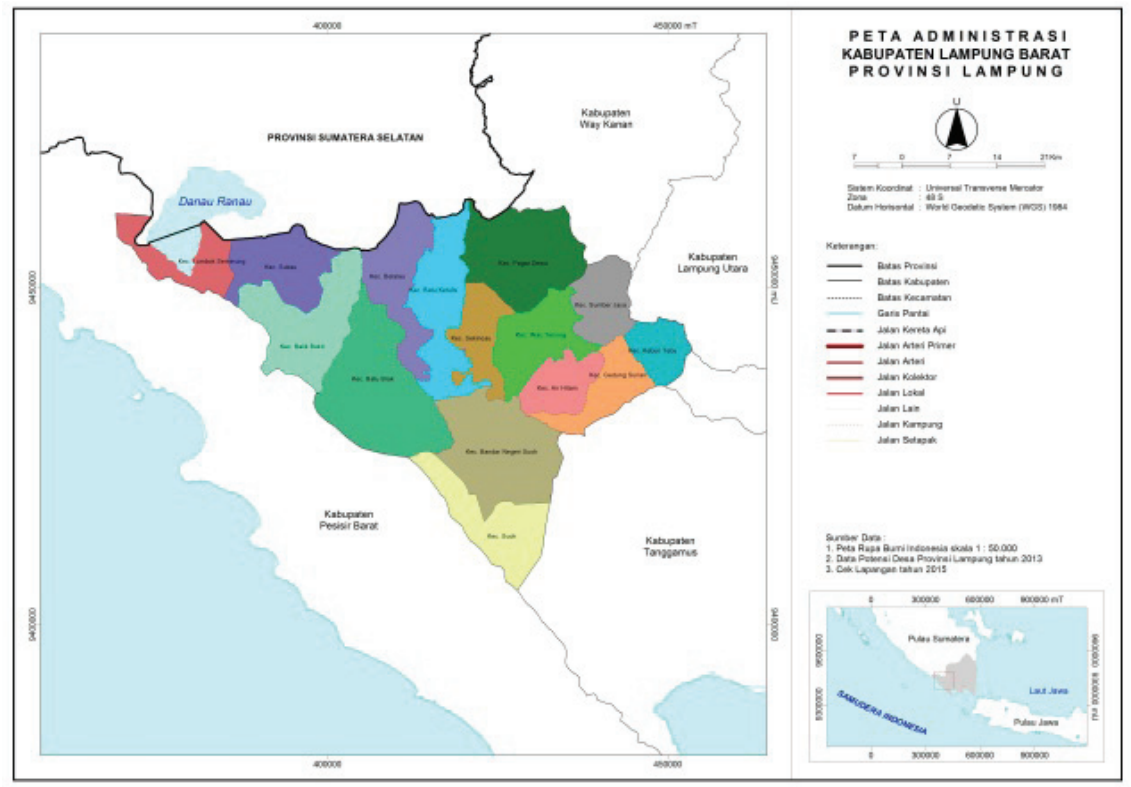

Figure 1. Administration Map of West Lampung

West Lampung as one of regencies in Lampung Province that esthablished by Statute No. 6 year of 1991 on August $16^{\text {th }} 1991$, is the result of the expansion of North Lampung Regency. The capital of regency is located in Liwa (Amroni, 2019). West Lampung has the potential of culture and it has very long history since this regency is central location of the establishment the Skala Brak Kingdom. Historically, Skala Brak kingdom was the greatest 
empire in Lampung Province and it played a role as a center for the distribution of native culture of Lampung (Hidayah, 2015).

As the location of the greatest empire at once a cultural center in Lampung, West Lampung Regency of course is very condensed with its customs and cultures (Susantri, 2019). Various local folklores also comes from this region. Some of the most well-known are Si Pahit Lidah and Si Mata Empat (The Story of The Bitter Tonguem and The Four Eyes) and Legenda tentang Naga Danau Ranau (the Legend of The Dragon Lake Ranau). However, Many folklores which come from West Lampung are not well documented and publicized. Therefore, efforts should be made to reintroduce and to preserve the folklores.

Therefore, this study aimed at making inventory and mapping of folklore in West Lampung of Lampung Province. Inventory and mapping were done through several steps include: 1) carrying out the inventory and mapping folklore in all regions of the West Lampung, 2) analyzing the cultural values and local wisdom contained in each folklore.

\section{Method}

The research was conducted using qualitative descriptive which was intended to describe certain social phenomena in detail, such as social interaction and kinship system. This research was used without hypothesis that has been formulated strictly, (Gelman \& Loken, 2016).

Qualitative descriptive method was used in this research to inventory, to map and to dig as many as possible of folklore in West Lampung Regency and they were analyzed in terms of cultural values and local wisdom contained in this folklore, so that it was known how it was applied in society in West Lampung Regency.

The subjects of this research were people who live in administrative area of West Lampung Regency which was also the population in this research and the object of the research was folklore. The sampling of population in this research was carried out by purposive sampling method with snowball pattern.

Purposive sampling was a technique to determine research sample with some specific considerations that aimed at making the data more representative (Sharma, 2017). In this research, the required sample acted as key informant where such samples must have the following criteria:

1) traditional leaders,

2) community leaders,

3) formal government leaders,

4) people who know about folklore in West Lampung

Snowball pattern also was applied in determining the sample so that respondents who were interviewed were able direct the next respondents (Heckathorn, 2011) to be more aware of the folklore in West Lampung. 
They were two types of data used in this study, namely primary data and secondary data (Heaton, 2008). Primary data were obtained directly from interviews at the respondents while secondary data were obtained indirectly or they were obtained through books and historical records related to the research theme. Primary data were collected through in-depth interview guided by a list of interview respondents were selected.

Data analysis was conducted to determine the cultural values contained in folklore in West Lampung. Furthermore, the data gained were validated through triangulation, involving experts and agents with information about the data (Torrance, 2012).

\section{Research result}

(Mac Coitir, 2016; Revika \& Hayati, 2020) states that folklore (folklore) can be divided into three major categories, namely: 1) myth, 2) legend, and 3) fairy tales. Based on data collection through in-depth interview on a few selected respondents and it was literature study, gained that in West Lampung there is 7 folklore are interesting and have cultural values, whether it is a myth, or legend: 1) Si Pahit Lidah "Bitter Tongue" and Si Mata Empat "the Four Eyes", 2) Naga Danau Ranau "Dragon Lake Ranau", 3) Asal mula nama Desa Sri Menanti "the origin of the name of the village of Sri Menanti", 4) Kisah Batu Katai dan Larangan Menikah antara warga Desa Gandasuli dan Desa Kunyanyan "Story of the Stone Katai and a ban on married between residents of Gandasuli Village and Kunyanyan Village", 5) Batu Kepampang "Kepampang Stone”, 6) Kisah Si Beguk Sakti “Acts of Si Beguk Sakti”, and 7) Asal usul nama Way Mengaku "origins the name of Way Mengaku".

If it is seen from the spreads, indeed folklore that exist in West Lampung spread across several districts, especially in the districts which was once the territory of the Skala Brak Kingdom and center of civilization such as District of Lumbok Seminung and around Lake Ranau, Black Water District, Sukau District, Belalau District, and Balik Bukit District. The complete distribution of each folklore can be observed in Table 1.

Table 1. Distribution of folklore based on territorial

\begin{tabular}{|c|l|l|}
\hline No & \multicolumn{1}{|c|}{ Folklore } & \multicolumn{1}{c|}{ Territorial } \\
\hline 1 & $\begin{array}{l}\text { Si Pahit Lidah "Bitter Tongue" and Si Mata } \\
\text { Empat "the Four Eyes" }\end{array}$ & Around Ranau Lake \\
\hline 2 & Naga Danau Ranau "Dragon Lake Ranau" & Around Ranau Lake \\
\hline 3 & $\begin{array}{l}\text { Asal mula nama Desa Sri Menanti "the origin of } \\
\text { the name of the village of Sri Menanti" }\end{array}$ & $\begin{array}{l}\text { Air Hitam District, West } \\
\text { Lampung }\end{array}$ \\
\hline 4 & $\begin{array}{l}\text { Kisah Batu Katai dan Larangan Menikah antara } \\
\text { warga Desa Gandasuli dan Desa Kunyanyan } \\
\text { "Story of the Stone Katai and a ban on married } \\
\text { between residents of Gandasuli Village and } \\
\text { Kunvanyan Village" }\end{array}$ & $\begin{array}{l}\text { Sukau District West } \\
\text { Lampung Regency }\end{array}$ \\
\hline
\end{tabular}




\begin{tabular}{|c|l|l|}
\hline 5 & Batu Kepampang “Kepampang Stone” & $\begin{array}{l}\text { Belalau District West } \\
\text { Lampung Regency }\end{array}$ \\
\hline 6 & Kisah Si Beguk Sakti “Acts of Si Beguk Sakti” & $\begin{array}{l}\text { Belalau District West } \\
\text { Lampung Regency }\end{array}$ \\
\hline 7 & $\begin{array}{l}\text { Asal usul nama Way Mengaku “origins the name } \\
\text { of Way Mengaku” }\end{array}$ & $\begin{array}{l}\text { Balik Bukit District West } \\
\text { Lampung Regency }\end{array}$ \\
\hline
\end{tabular}

Sources: Field Data, 2019

Based on the results of further analysis, there are 7 (seven) folklore originating from the West Lampung district that can be classified into types of myths and legends. A complete classification of each folklore can be seen in Table 2.

Table 2. Classification types of folklore in West Lampung Regency

\begin{tabular}{|c|l|l|}
\hline No & \multicolumn{1}{|c|}{ Types } & \multicolumn{1}{c|}{ Folklore Title } \\
\hline 1 & \multirow{2}{*}{ Myth } & $\begin{array}{l}\text { Story of the Stone Katai and a ban on married between } \\
\text { residents of Gandasuli Village and Kunyanyan Village }\end{array}$ \\
\cline { 3 - 3 } & & The origin of the name village of Sri Menanti \\
\cline { 3 - 3 } & & Origins the name of Way Mengaku \\
\hline 2 & \multirow{2}{*}{ Legend } & Bitter Tongue and the Four Eyes \\
\cline { 3 - 4 } & & Dragon of Lake Ranau \\
\cline { 3 - 4 } & & Kepampang Stone \\
\cline { 3 - 3 } & & Acts of Si Beguk Sakti \\
\hline
\end{tabular}

Sources: Analisis Data, 2019

Each folklore located in West Lampung also has cultural values inherently in them and it can be used as guidelines and a lesson in life in society. For example the story of the bitter tongue and The Four Eyes that teach about social values which the overbearing nature can destroy itself. So, the story of the origin of the name Desa Sri Menanti that teaches about the sincerity and loyalty of a woman. A complete cultural values contained in each folklore can be observed in Table 3.

Table 3. Cultural Values contained in Folklore in West Lampung Regency

\begin{tabular}{|c|c|c|}
\hline No & \multicolumn{1}{|c|}{ Folklore } & \multicolumn{1}{c|}{ Cultural Values } \\
\hline 1 & Si Pahit Lidah dan Si Mata Empat & Social Value, Nature of Vanity \\
\hline
\end{tabular}




\begin{tabular}{|c|l|l|}
\hline 2 & Cerita Naga Danau Ranau & Social Value, Nature of Greed \\
\hline 3 & Asal mula nama Desa Sri Menanti & Social Value, Nature of Faithfulness \\
\hline 4 & $\begin{array}{l}\text { Kisah Batu Katai dan Larangan menikah } \\
\text { antara warga Desa Gandasuli dan Desa } \\
\text { Kunyanyan }\end{array}$ & $\begin{array}{l}\text { Social Value, Nature of Envy and } \\
\text { Greed }\end{array}$ \\
\hline 5 & Batu Kepampang & Religious Value \\
\hline 6 & Kisah Si Beguk Sakti & Religious Value \\
\hline 7 & Asal-usul nama Way Mengaku & Social Value Customs \\
\hline
\end{tabular}

Sumber: Field Data, 2019

Currently, all of the folklores in West Lampung are still handed down through they generations across generations and are still used as a guide for some people who live there. Most of them do not dare to break the myths that are told in the stories of the people because they believed in the truth of myth or legend in folklore they hear (Bulfinch, 2014; Ellis, 1994).

There are 7 (seven) folklore from West Lampung that are not yet widely publicized so that they are known by the people who live in other provinces. Therefore we need an effort to publish more widely so that folklore is better known by people in Indonesia. Publications can be done in several ways, such as packaged in the form of a book of fairy tales (hardcopy) or through electronic form, either through writing on websites officially belong to the relevant office in West Lampung and through applications that can be accessed via smartphones and gadgets, The hope with the increasing number of publications how the richness of Indonesian culture in the form of folklore can continue to be preserved and serve as guidelines for life in society (Herzfeld, 2020; Roginsky, 2007).

\section{Conclusion}

There are 7 (seven) folklores originating from West Lampung regency. Folklore in West Lampung spread across several regions include: Lumbok Seminung District and around Lake Ranau, Air Hitam district, Sukau district, Belalau district, and Balik Bukit district. 7 (seven) folklores can be classified into two (2) types, namely myths and legends. Cultural values contained in folklore at the Regency of West Lampung is dominated by religious values and social values of humanity. Until now the cultural values that exist in each folklore is still used as a guide for the people in the Regency of West Lampung.

\section{References}

Albekov, T. K., Alpysbayeva, K. B., \& Tenizbayevna, P. J. E. (2017). Distinctive and educational features of Kazakh folklore by the example of «Words of Ancestors». 38(45), 33-34.

Amroni, Y. (2019). Analisis dampak pemekaran wilayah terhadap pertumbuhan ekonomi di kabupaten 
lampung barat dalam perspektif ekonomi Islam Tahun 2010-2016 (Analysis of the Impact of regional expansion on economic growth in west lampung regency in the perspective of Islamic Economics in 2010-2016). UIN Raden Intan Lampung,

Bailey, F. G. (2017). Morality and expediency. Transaction Publishers.

Beneduce, R. J. T. p. (2016). Traumatic pasts and the historical imagination: Symptoms of loss, postcolonial suffering, and counter-memories among African migrants. 53(3), 261-285.

Bronner, S. J. (2016). Folklore: The basics: Taylor \& Francis.

Buchan, D. (2015). The ballad and the folk (RLE Folklore): Routledge.

Bulfinch, T. (2014). Bulfinch's Mythology: The classic introduction to myth and legend-complete and unabridged: Penguin.

Cleveland, M., Rojas-Méndez, J. I., Laroche, M., \& Papadopoulos, N. J. J. o. B. R. (2016). Identity, culture, dispositions and behavior: A cross-national examination of globalization and culture change. 69(3), 1090-1102.

De Mooij, M. (2018). Global marketing and advertising: Understanding cultural paradoxes: Sage.

Deming, A., \& Lihui, Y. J. A. E. (2015). Chinese folklore since the late 1970s: achievements, difficulties, and challenges. 74(2), 273.

Ellis, B. J. F. (1994). “The hook” Reconsidered: Problems in classifying and interpreting adolescent horror legends. 105(1-2), 61-75.

Gates Jr, H. L. (2016). Black literature and literary theory: Routledge.

Gelman, A., \& Loken, E. J. T. b. w. o. m. (2016). The statistical crisis in science. 305-318.

Grimm, J., \& Grimm, W. (2016). The original folk and fairy tales of the brothers Grimm: The complete first edition: Princeton University Press.

Grishina, I. I., \& Vinokurova, Y. I. (2015). Poetic fiction as a means of choosing a fairytale in educational process for different aged groups of readers.

Humanities \& Social Sciences 11 (2015 8) 2341-2347.

Heaton, J. J. H. S. R. H. S. (2008). Secondary analysis of qualitative data: An overview. 33-45.

Heckathorn, D. D. J. S. m. (2011). Comment: Snowball versus respondent-driven sampling. 41(1), 355-366.

Hermanto, Y. A. L. J. A. J. o. R. i. E., \& Sciences, S. (2019). Visual storytelling in folklore children book illustration. 1(1), 62-70.

Herzfeld, M. (2020). Ours once more: Folklore, ideology, and the making of modern Greece: Berghahn Books.

Hidayah, Z. (2015). Ensiklopedi suku bangsa di Indonesia: Yayasan Pustaka Obor Indonesia.

Korhonen, T. J. H. (2017). A question of life and death: The aesopic animal fables on why not to kill. $6(2), 29$.

Korom, F. J., \& Lowthorp, L. K. (2020). South Asian folklore in transition: Crafting new horizons: Routledge. 
Lévi-Strauss, C. (2016). We are all cannibals: And other essays: Columbia University Press.

Mabey, R. (2016). The cabaret of plants: Forty thousand years of plant life and the human imagination: WW Norton \& Company.

Mac Coitir, N. (2016). Ireland's trees-myths, legends \& Folklore: Gill \& Macmillan Ltd.

Marsh, M. (2015). Practically joking: University Press of Colorado.

Mingazova, L. I., Galimullin, F. G., Galimullina, A. F. J. T. o. j. o. d. a., \& communication. (2016). The mythological image of shuralen and its reflection in the folklore of Volga-Ural region. 6, 32563262 .

Mollet, T. L. (2020). A cultural history of the disney fairy tale: Once upon an American dream: Springer.

Nwauche, E. (2017). Traditional cultural expressions in Africa. In The Protection of Traditional Cultural Expressions in Africa (pp. 11-51): Springer.

Revika, R., \& Hayati, Y. J. R. J. B., Sastra, dan Pengajarannya. (2020). Categories, structure, and function of folklore in Lima Puluh District Communities. 13(1), 137-145.

Roginsky, D. J. J. o. F. R. (2007). Folklore, folklorism, and synchronization: Preserved-created folklore in Muse, Israel. 41-66.

Salehan, M., Kim, D. J., Lee, J.-N. J. I., \& Management. (2018). Are there any relationships between technology and cultural values? A country-level trend study of the association between information communication technology and cultural values. Managing Global Transitions 55(6), 725-745.

Samovar, L. A., Porter, R. E., McDaniel, E. R., \& Roy, C. S. (2017). Communication between cultures. Nelson Education.

Schuurmans, J., \& Monaghan, L. F. J. S. R. O. (2015). The Casanova-Myth: legend and anxiety in the Sociological Research Online. 20(1), 94-107.

Sharma, G. J. I. j. o. a. r. (2017). Pros and cons of different sampling techniques. International Journal of Applied Research, Joged, Jurnal Seni Tarı, 3(7), 749-752.

Silverman, Y. (2020). The story within-myth and fairy tale in therapy: Jessica Kingsley Publishers.

Steger, M. B. (2017). Globalization: A very short introduction (Vol. 86): Oxford University Press.

Susantri, A. J. J. J. S. T. (2019). Tari Sekura sebagai media pelestari topeng sekura dari Liwa Lampung Barat (Sekura Dance as a Media to Preserve the Sekura Mask from Liwa, West Lampung). 13(2), 158-170.

Tatar, M. (2017). The classic fairy tales (Second international student edition) (Norton Critical Editions): WW Norton \& Company.

Tolkach, D., \& Pratt, S. J. T. G. (2019). Globalisation and cultural change in Pacific island countries: The role of tourism. https://doi.org/10.1080/14616688.2019.1625071

Torrance, H. J. J. o. m. m. r. (2012). Triangulation, respondent validation, and democratic participation in mixed methods research. Journal of Mixed Methods Research 6(2), 111-123.

Unger, J. (2016). Chinese nationalism: Routledge.

White, R. S. J. J. o. t. A. P. A. (2017). Fire in the dragon and other psychoanalytic essays on folklore, 
An introduction to the psychology of fairy tales and the uses of enchantment: The meaning and importance of fairy tales. 65(4), 705-728.

Widyahening, S., Wardhani, M. J. I. j. o. 1., \& literature. (2016). Literary works and character education. 4(1), 176-180.

Windling, T. J. J. o. t. F. i. t. A. (2017). Into the woods. $28(1$ (98), 33-45.

Wood, J. (2018). Fantastic creatures in mythology and folklore: From Medieval times to the present day: Bloomsbury Publishing.

Zipes, J., Greenhill, P., \& Magnus-Johnston, K. (2015). Fairy-tale films beyond Disney: International perspectives: Routledge.

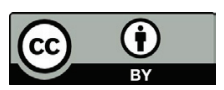

Bu eser Creative Commons Atıf 4.0 Uluslararası Lisansı ile lisanslanmıştır.

(This work is licensed under a Creative Commons Attribution 4.0 International License). 